Aud Marit Simensen

Institutt for lcererutdanning og skoleforskning, Universitetet i Oslo

\title{
Skolefaget engelsk. Fra britisk engelsk til mange slags "engelsker"- og veien videre
}

\section{Sammendrag}

I artikkelen redegjør jeg for valg av engelskvariant i skolefaget engelsk i Norge, fra Skoleloven av 1936, da engelsk ble innført som fag i den obligatoriske folkeskolen, og fram til i dag. Skolefagets lcereplaner utgjør her kildene til kunnskap om en engelskvariant som modell for elevenes egen laring av uttale, elevenes forståelse av ulike uttalevarianter og opprinnelseslandet til kulturelementer representert. Analysen viser at først i 1987 ble de to tradisjonelle hovedvariantene av engelsk uttale, britisk engelsk og amerikansk engelsk, formelt likestilt. Denne læreplanen hadde videre som målsetting at elevene skulle lytte til uttalevarianter også fra verden utenfor Storbritannia og USA og lere å akseptere dem som likeverdige. I den påfølgende planen fra 1997 skulle elevene også lcere å oppfatte varianter av engelsk. Både 1987- og 1997planen refererer til engelsk som internasjonalt språk, men først i læereplanen fra 2006 konkretiseres dette blant annet ved at elevene skal få innsikt i hvordan språket brukes som internasjonalt kommunikasjonsmiddel. Kulturkomponenten $i$ skolefaget blir ikke studert per se i artikkelen, men trekkes inn i den grad den kan forstås som en drivkraft for valg av språkvariant. I en kortfattet ramme rundt artikkelens hovedmålsetting skiller jeg blant annet mellom hovedtyper brukere av engelsk, og jeg redegjør for den internasjonale debatten i samtiden om å gjøre engelsk som lingua franca til modell for opplæringen.

\section{Innledning}

Det engelske språkets stilling i verden har endret seg fullstendig. Og det vi vanligvis forstår som "engelsk språk” har også endret seg radikalt. Engelsk er for eksempel blitt et globalt eller internasjonalt språk og blir brukt i daglig kommunikasjon i alle verdensdeler. Dette har vært et viktig utgangspunkt for denne artikkelen.

I Norge har engelsk tradisjonelt hatt status som fremmedspråk. Imidlertid var det allerede på 1990-tallet en oppfatning om at engelsk i Norge, i likhet med i flere andre land, var i ferd med å skifte status fra et fremmedspråk til et annetspråk (Graddol, 1997, s. 11). Utstrakt bruk av engelsk i næringslivet, studier i utlandet, ingen “dubbing” av engelskspråklige filmer osv. blir regnet til 
forklaringene. Jeg bruker betegnelsen 'fremmedspråk' her om engelskfaget i det norske skolesystemet.

I engelskfaglige akademiske disipliner er en i dag mer opptatt enn tidligere av å skille mellom og beskrive flere varianter av engelsk enn de tradisjonelle variantene britisk engelsk og amerikansk engelsk, som for eksempel indisk engelsk og ghanesisk engelsk. I noen grad gjelder også det engelsk som lingua franca (ELF). Ulike engelskvarianter har derfor også vært et viktig utgangspunkt for denne artikkelen.

Hovedmålsettingen med artikkelen er å redegjøre for og drøfte valg av variant av engelsk som språklig mål, standard, norm eller modell for opplæringen i det norske skolesystemet, både i tilbakeblikk og som del av veien videre i skolefaget. I den grad mine kilder gjør det mulig, skal jeg konsentrere meg om skolesystemets valg av uttalevariant. Det er engelsk som skolefag etter den annen verdenskrig som blir temaet i artikkelen ettersom det er i denne perioden situasjonen for det engelske språkets stilling i verden har endret seg mest. Og igjen, i den grad mine kilder gjør det mulig, skal jeg studere i hvilken grad endringene har påvirket skolefaget.

Kultur og språk henger nøye sammen, men kulturbegrepet trekkes bare inn her i den utstrekning det kan tenkes å avspeile en interesseorientering og dermed kan ha hatt påvirkning på valg av engelskvariant.

I rammen rundt artikkelens hovedtema skisserer jeg hovedtrekkene i den globale spredningen av det engelske språket og redegjør for de ulike hovedfunksjonene engelsk fyller for ulike typer brukere, samt berører noen sentrale temaer innenfor fagfelt som studerer de "engelsker" som går under betegnelsen World Englishes eller New Englishes og ELF.

\section{Materiale og fremgangsmåte}

I denne artikkelen utgjør skolefagets læreplaner i perioden fra 1939 til i dag kildene til innsikt i opplæringen i faget. En naturlig avgrensing for denne artikkelen har vært å studere læreplanene for grunnutdanningen, det vil si opplæringsnivået som inkluderer flest mulig av elevene på det aktuelle tidspunktet i skolefagets historie, og som en i en formell utdanningssammenheng vanligvis regner som det nivået hvor et viktig grunnlag for en uttalevariant legges. Det betyr den obligatoriske folkeskolen eller grunnskolen i det norske utdanningssystemet. Tidspunktet for innføringen av engelsk som fag i den obligatoriske folkeskolen blir derfor det naturlige startpunktet for drøftingene. Dette skjedde med skolelovene av 1936 og med læreplanen for engelsk i folkeskolen, nedfelt i Normalplan av 1939. ${ }^{1}$ Med denne loven var det imidlertid opp til den enkelte kommune om den ville innføre engelsk som fag i sine skoler. Naturlig nok medførte dette store forskjeller mellom kommunene 
(jf. Stensaasen, 1958). Først med grunnskoleloven av 1969 ble engelsk et obligatorisk fag for alle elevene.

Læreplaner er normalt ganske generelle dokumenter, så det trengs forskning på andre kilder, blant annet på lærebøker og evalueringsinstrumenter, for å kunne gi en noenlunde fullstendig fremstilling av skolefaget over tid. I tillegg har graden av spesifisering variert fra plan til plan. En læreplan har for eksempel definert som et minstekrav at elevene ved slutten av kurset skal ha tilegnet seg "[...] evne til å forstå, lese, tale og skrive språket innenfor et sterkt avgrenset område” (Normalplan for byfolkeskolen av 1939, s. 235). En annen læreplan, flere tiår senere, har spesifisert leseferdigheten på følgende måte "En ferdighet er evnen til å lese på det fremmede språket, og til å forstå innholdet i det en leser” (Mønsterplan for grunnskolen av 1974, s. 147). I dagens gjeldende læreplan, Kunnskapsløftet av 2006, er spesifiseringene av de ulike ferdighetene langt mer omfattende.

De aktuelle læreplanene har dessuten i betydelig grad endret fokus og vektlegging i den perioden vi her studerer. I tidsrommet 1939 til 1974 er de for eksempel preget av at de blant annet hadde som funksjon å endre undervisningsmetoden i engelskfaget, fra en type grammatikk-oversettelses-metodisk tilnærming til en mer direkte og etter hvert audiolingvalt og kommunikativt orientert undervisning. Mens etter tusenårsskiftet er fokus og vektlegging på klarere spesifiseringer av målsettinger i faget og definisjoner av forventet nivå på de forskjellige stadier i opplæringen. Kunnskapsløftet av 2006 er eksempel på dette.

De aktuelle læreplanene i engelsk analyseres ut fra hva de sier om

- engelskvariant som modell for elevenes egen læring, i hovedsak av uttale,

- uttalevariant(er) som elevene skal eksponeres for

- det/de land som kulturkomponenten i skolefaget engelsk skal hentes fra.

Jeg trekker også inn i diskusjonen noen resultater av et utvalg undersøkelser i samtiden av holdninger til og meninger om valg av uttalevarianten blant norske elever og lærere. Hva angår fremgangsmåte i avsnittene om det norske skolefaget, er kronologi det bærende prinsipp.

Til rammen rundt artikkelens hovedmålsetting har jeg utnyttet en rikholdig faglitteratur. Ikke minst gjelder det litteratur som redegjør for den tidsaktuelle internasjonale debatten om valg av variant for undervisningsformål.

Spredningen av engelsk

Makt - politisk, militær og økonomisk - blir i faglitteraturen nevnt som den viktigste forklaringen på at et språk sprer seg. Utbredelsen av engelsk ut over 
sine nærområder begynte for fullt i det 17. århundre, i særdeleshet med utvandringen fra de britiske øyene til Nord-Amerika og etableringen av de amerikanske koloniene (jf. Graddol, 1997, s. 6).

Politisk, militær og økonomisk makt har også vært forklaringen på spredningen av engelsk etter etableringen på det nordamerikanske kontinent. I denne prosessen var det to hovedaktører: Storbritannia og USA. I det britiske imperium ble naturlig nok engelsk administrasjonsspråket, noe som avspeiler seg i de mange land som fortsatt har engelsk som offisielt språk, for eksempel i Ghana hvor engelsk også i dag er "the main language of the education system and print media" (Shoba \& Quarcoo, 2012, s. 77; jf. også nedenfor). Etter den annen verdenskrig var det USA, som den ledende politiske, militære og økonomiske supermakten, som sikret det engelske språkets hegemoni.

Blant forklaringene til den videre spredningen av engelsk etter den tid er den stillingen engelsken har som det viktigste språket i internasjonale organisasjoner, internasjonal reisevirksomhet, akademiske disipliner, media, populærkultur og elektronisk kommunikasjon. Noen skribenter knytter også spredningen av engelsk til håp generelt og materiell fremgang spesielt (jf. for eksempel Steiner, 1975, s. 469, sitert i Graddol, 1997, s. 8).

\section{Tre hovedtyper brukere}

Det er vanlig å skille mellom tre hovedtyper brukere av engelsk. Det er de som bruker engelsk som førstespråk, det språket språkbrukerne har lært først. Dernest er det de som bruker engelsk som annetspråk. Sistnevnte har allerede tilegnet seg et førstespråk, men ettersom de normalt bor i et flerspråklig samfunn, må de bruke et annet språk i forbindelse med utdanning, arbeidsliv osv., som for eksempel i den tidligere britiske kolonien Ghana, som omtalt ovenfor. Den tredje hovedgruppen brukere av engelsk er de som bruker språket som fremmedspråk. Det betyr vanligvis språkbrukere som har fått opplæring i dette språket i et utdanningssystem, så som i Norge.

Lingvisten Braj B. Kachru har i flere sammenhenger visualisert i hvilke land disse tre typer brukere i overveiende grad hører hjemme. Dette har han gjort i form av tre Concentric Circles of English (jr. for eksempel Kachru, 1986, 1996). I den "indre" (inner) sirkelen plasserer han land hvor brukerne har engelsk som førstespråk, i den "ytre" (outer) sirkelen land hvor brukerne har engelsk som annetspråk, og i den "voksende" (expanding) sirkelen plasserer han land hvor engelsk brukes som fremmedspråk. Det gjelder for eksempel i de nordiske landene (Kachru, 1996, s. 137). Følgende er en kraftig forenkling av Kachru (1996): 


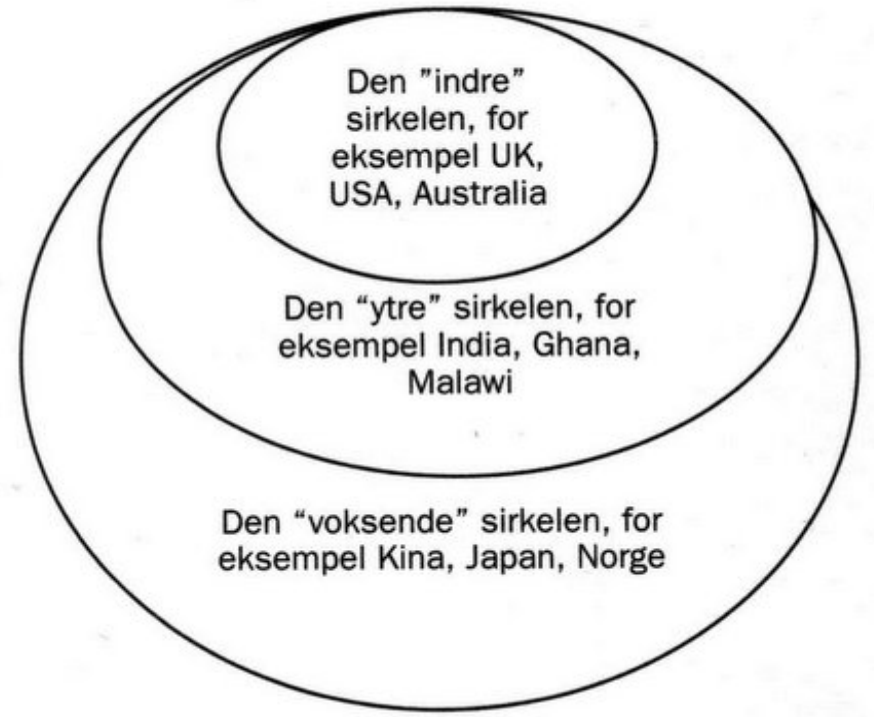

I senere arbeider har antagelser om antall brukere blitt utvidet. I 1997 var for eksempel antagelsen for den "indre" sirkelen 320-380 millioner brukere, for den "ytre" sirkelen 150-300 millioner, og for den "voksende" sirkelen det svært omtrentlige tallet 100-1000 millioner (Crystal, 1997, s. 54).

Den "voksende" sirkelen synes å være den som er vanskeligst å holde oversikt over. Ifølge British Council er antagelsen i dag at den omfatter 750 millioner brukere. ${ }^{2}$ Oppjusteringer av tallene gjelder naturligvis også de andre sirklene, for eksempel ved at befolkningsgrupper i land som tidligere ikke var registrert i den "indre” sirkelen nå er blitt det. Dette gjelder blant annet befolkningsgrupper i Sør-Afrika. I tillegg viser David Graddol til at det er en tendens til at profesjonelle og middelklassegrupper som er bilingvale, for eksempel borgere i utviklingsland, velger engelsk som hjemmespråk (Graddol, 1997, s. 11). Det betyr at barn som vokser opp i slike miljøer faktisk får engelsk som førstespråk. ${ }^{3}$ Likevel er en ting hevet over all tvil, og det er at brukere av engelsk som førstespråk i dag er i mindretall. Noe som videre vekker atskillig oppmerksomhet, er en antagelse om at i $80 \%$ av situasjonene hvor engelsk brukes, er det ingen bruker(e) av engelsk som førstespråk til stede (Gnutzmann, 2000, sitert i Burt, 2005). Det er derfor en betydelig spenning innenfor flere fagfelt, blant annet innenfor engelskdidaktiske disipliner, om hvilke konsekvenser dette kan ha.

Engelsk som annetspråk spesifisert som World Englishes eller New Englishes

På det tidspunkt Kachrus modell først ble lansert, ble språkbrukerne i den "indre" sirkelen nærmest betraktet som de som eide det engelske språket. Gjennom karakteristikken norm-providing om denne engelsken ble det implisert 
at det er de som setter en standard eller definerer normen for hvordan språket skal være (Kachru, 1982). Samtidig betraktet Kachru språkbrukerne i den "ytre" sirkelen som i ferd med å utvikle sine egne varianter, blant annet ved at han brukte karakteristikken norm-developing om dem. Det er verdt å legge merke til at brukerne i den "voksende" sirkelen i modellen på det tidspunkt ikke eksplisitt var "tilkjent" retten til å utvikle sine egne varianter. De ble regnet som normdependent (jf. nedenfor).

I dag har flere varianter av engelsk i den "ytre" sirkelen, normalt omtalt som World Englishes eller New Englishes, fått stor oppmerksomhet blant språkforskere. Etableringen av tidsskrifter med navn som English Today og World Englishes fra 1985 og utover vitner om det. Og vi har fătt karakteristikken "naturaliserte" varianter av engelsk ("indigenized") med spesifiseringer som Indian English, Nigerian English osv. ${ }^{4}$ Viktige kriterier for å kunne karakteriseres som "naturalisert" og dermed kunne kategoriseres i gruppa World Englishes er, ifølge Sandra Mollin, at det har funnet sted en utvikling av

“[...] unique linguistic features, which need to be communal and systematic so that we can speak of a variety that is in form systematically different from native-speaker varieties” (Mollin, 2006a, s.198).

Samtidig har Kachru, født og oppvokst i India, hevdet at "there are as many Indian Englishes as there are languages of India” (Kachru, 1992, sitert i Bolton, 2005, s. 75). ${ }^{5}$

Noen naturaliserte "engelsker" er beskrevet hva angår både uttale, morfologi, vokabular og syntaks. Det ligger en rekke språkeksempler på Internett (jf. for eksempel Language in India, en open access journal med blant annet en enkel innføring av Jason Baldridge, 2002). Eksempler på andre naturaliserte varianter, som for eksempel nigeriansk engelsk, også med eksempler på uttale, finnes i Andy Kirkpatricks bok fra 2007.

I kategorien World Englishes hører engelskvarianter som ligger nær opp til de tradisjonelle standardvariantene britisk engelsk og amerikansk engelsk så vel som varianter som er svært forskjellig fra disse. En av de to hovedvariantene av engelsk som tales i Singapore, populært kalt "Singlish", blir regnet til de sistnevnte, mens varianten Standard Singapore English blir regnet til de førstnevnte. Myndighetene har satt i gang en årlig "Speak Good English Movement” for å stimulere til bruk av standardvarianten. Ifølge forskning på gang i samtiden kan de to tradisjonelle standardvariantene britisk engelsk og amerikansk engelsk etter hvert bli supplert med beskrivelser av nye standardvarianter som kanadisk engelsk, karibisk engelsk osv. (jf. Hickey, 2012). 


\section{Engelsk som lingua franca: en utfordrende debatt}

En kortdefinisjon av ELF er at det er et "kontaktspråk". En mer utførlig definisjon sier at det er "an additionally acquired language system which serves as a common means of communication for speakers of different first languages" (Jenkins, Cogo \& Dewey, 2011, s. 283). I faglitteraturen om engelskens rolle som kontaktspråk de siste 20-30 årene brukes også en rekke andre betegnelser så som 'engelsk som verdensspråk, 'som globalt språk', og 'som internasjonalt språk’ ${ }^{6}$

Mye tyder på at ELF etter hvert har blitt den mest brukte betegnelsen, og at det i samtiden er stor faglig interesse for denne funksjonen av engelsk. Enkelte refererer sågar til dette som Lingua Franca Movement (Berns, 2009). Dette til tross påviste forfatterne Jennifer Jenkins, Alessia Cogo \& Martin Dewey i 2011 at en veletablert lærebokforfatter på feltet engelskdidaktikk, Jeremy Harmer, så sent som i 2007, nærmest i forbifarten, skriver om the newly-observed phenomenon that is sometimes called ELF (Harmer, 2007, s. 10, sitert i Jenkins, Cogo \& Dewey, 2011, s. 305).

Interessen for ELF blant fagfolk med ansvar for engelskopplæring synes for alvor å ha startet ved tusenårsskiftet, ikke minst på grunn av påstander om at en undervisning basert på innfødt engelsk uttale som britisk engelsk og amerikansk engelsk, ikke var optimal for elever og studenter med tanke på de internasjonale kommunikasjonssituasjonene de på sikt ville komme i. Det ble også fremført argumenter om å gjøre ELF til språklig modell for undervisningen i engelsk som fremmedspråk (Jenkins, 2000).

Naturlig nok ble det ganske umiddelbart vist til et behov for å kunne identifisere formelle og funksjonelle sider ved ELF for å kunne ha det som et undervisningsfag. Det ble hevdet at beskrivelser eller kodifisering var nødvendig, blant annet av uttale, ikke minst med tanke på å utvikle kriterier for evaluering og prøving av elevers engelskkompetanse. For å komme et slikt behov i møte begynte sentrale talspersoner for ELF som språklig modell å samle inn materiale (korpus) av ELF-bruk, blant annet et korpus fra akademia og et fra ELF-bruk i Asia (jf. spesifiseringer i Jenkins, Cogo \& Dewey, 2011, s. 282). Interessen for ELF som forskningstema har bare økt de senere årene, og i 2012 så Journal of English as a Lingua Franca dagens lys.

Spørsmålet om en egen ELF-variant i vår del av verden ble reist på 1990tallet. Marko Modiano hevdet for eksempel at britisk engelsk nok hadde vært den ubestridte modellen i Europa fram til 1970-tallet, men fremholdt at en bevegelse i retning av en Midt-Atlantisk variant var merkbar allerede på 1980tallet og fikk stor utbredelse utover på 1990-tallet (Modiano, 1996). Han brukte betegnelsen Euro-English om denne varianten. Hans spådde blant annet at en Midt-Atlantisk variant, kort definert som en "mixing of AmE and BrE", ville komme til å erstatte britisk engelsk som foretrukket standard for engelskfaget i de europeiske utdanningssystemene (s. 208). Han hevdet videre at de 
kommunikative ferdighetene til studenter og yngre profesjonelle mennesker ville unngjelde dersom språkopplæringen ikke inkluderte øving i blant annet å forstå brukere av andre engelskvarianter og dessuten ikke oppmuntret elever og studenter til selv å bruke internasjonalt aksepterte språklige særtrekk fra disse når det var høvelig (s. 209).

Jennifer Jenkins og Barbara Seidlhofer, pionerer innen ELF-feltet omkring tusenårsskiftet, hadde relativt klare oppfatninger om hvordan en ELF-variant i Europa, Euro-English, ville kunne utvikle seg (Jenkins \& Seidlhofer, 2001). Med utgangspunkt i innhentet materiale om ELF-bruk hevdet de for eksempel at det var lite sannsynlig at de engelske th-lydene, som for eksempel i think og this, ville bestå i Euro-English siden så mange talere av europeiske språk har problemer med dem. De mente det var sannsynlig at lyden $/ \theta /$ etter hvert ville bli byttet ut med lydene /s/ (tyske talere) eller /t/ (norske talere) og at /ð/ ville bli byttet ut med /z/ (tyske talere) eller /d/ (norske talere) som normalformer. De mente videre at disse uttale-"feilene" ikke utgjorde noe hinder for forståelsen for lytteren, og det var dårlig anvendt tid å terpe på denne type problemer i undervisningen ettersom mange gjør feil uansett, særlig i spontan språkbruk, og at tiden klart kunne utnyttes bedre. De mente også at i likhet med andre som lærer seg engelsk for internasjonal bruk, måtte de som lærer seg Euro-English få en undervisning basert på opptak av språklig interaksjon mellom ikke-innfødte talere av engelsk i Europa og fra de typer sosiale sammenhenger hvor også elevene/studentene selv etter all sannsynlighet senere ville kunne forventes å delta.

Tanken om at en Euro-English-variant allerede eksisterte, hadde sine støttespillere. Men slett ikke alle var av samme mening. Det gjaldt blant annet Sandra Mollin. Meg bekjent er Euro-English-studien hennes fra 2006 den mest omfattende (Mollin, 2006a). Ut fra det materialet hun samlet inn og analyserte, stilte hun spørsmålet: Why is ELF not included as the variety of a normdeveloping Expanding Circle?. Og hennes svar er:

Corpus evidence from the Euro-English project has been cited to support the view that ELF does not count as a variety as such, since it appears to lack coherent features marking it off from other varieties (Mollin, 2006b, s. 54, jf. kriterier ovenfor for å regnes som en "naturalisert” variant).

Jeg skal vende tilbake til dette spørsmålet nedenfor i avsnittet "Diskusjon om veien videre”.

\section{Skolefaget engelsk i læreplanene}

Som redegjort for under "Materiale og fremgangsmåte" ovenfor, ble tidspunktet for innføringen av engelsk som fag i den obligatoriske opplæringen brukt som 
det naturlige startpunktet for drøftingene av engelskfaget i grunnutdanningen. Den første aktuelle læreplanen var Normalplan av 1939 (N-39).

Både i denne planen og den påfølgende Plan for en engelskundervisning for alle av 1957 (P-57) brukes betegnelsene "engelsk", "engelske ord”, "engelsk(e) tekst(er)” og i sistnevnte også "engelsk tale” om språket. I førstnevnte plan vises det videre til en del av kulturaspektet i faget som "Områder av dagliglivet” med spesifikasjoner som "Heimen og livet der”, "Bygd og by” osv. (s. 237). I P-57 utvides kulturaspektet til også å gjelde "Amerika", gjennom formuleringen "Opplysninger om hverdagsliv i England og Amerika” (s. 169). P-57 inkluderer også en liste over ord, alle i britisk engelsk ortografi. Det er rimelig å tolke det intenderte språket i både N-39 og P-57 til å gjelde språket i England. Det kan for eksempel i utstrakt grad tilskrives den omfattende assistanse skolesystemet i Norge fikk fra British Council fra 1930-tallet og i flere tiår framover. Sentralt i dette stod blant annet etterutdanningskurs for engelsklærere gitt av innfødte talere av britisk engelsk (Gundem, 1989, sitert i Simensen, 2011).

I Lcereplan for Forsøk med 9-årig skole av 1960 (L-60), videreføres omtalen av språket bare som "engelsk", mens kulturaspektet spesifiseres på følgende måte: "[...] å gi elevene en innføring i dagliglivet, historien og geografien og ungdomslitteraturen i de engelsktalende land (Storbritannia og de andre Samvelde-landene, De forente stater)" (s. 204). Den noe forsiktige nyorienteringen på kulturfeltet som vi ser her, og som vi også observerte antydet i foregående plan, avspeiles også i omtalen av pensum hvor det heter at "Amerikansk stoff (med britisk-engelsk ortografi) skal være representert med ca. 25 sider" (s. 233, uthevet her). Dette til tross, med språket engelsk menes utvilsomt britisk engelsk.

Den neste fagplanen i rekken, Mønsterplan for grunnskolen av 1974 (M-74), representerer en ytterligere utvidelse av oppfatningen av det engelske språkets funksjon, idet planen refererer til engelsk som kommunikasjonsmiddel i en enda videre sammenheng enn de tradisjonelle engelsktalende land og samveldelandene gjennom følgende formulering: "Gjennom det lærestoff elevene arbeider med, skal de få kjennskap til forholdene før og nå i Storbritannia og USA og til den rolle det engelske språk spiller som kommunikasjonsmiddel ellers i verden” (s.147). Elevene skal riktignok bare ha noe kjennskap til språkets rolle på denne tiden, for når det gjelder den variant elevene selv skal lære, sies det at modellen for den engelske uttalen bør være English Standard Pronunciation. Men så legges det til: "Det vil være nyttig for elevene å bli gjort oppmerksom på typiske trekk ved amerikansk uttale. En elev som har lært amerikansk engelsk, bør ikke påtvinges britisk uttale, ortografi og vokabular” (s. 149). Dette er et steg på veien mot en likestilling av de to store uttalevariantene.

Den neste utgaven av mønsterplanen, Mønsterplan for grunnskolen av 1987 (M-87), uttrykker generell aksept for amerikansk engelsk uttale. I tillegg har denne læreplanen som ambisjon å endre noen holdninger hos eleven: "Eleven 
skal få høre eksempler på ulik uttale av det engelske språket, og lære å respektere ulike uttalevarianter som likeverdige” (s. 207). Vi har ikke noen nærmere spesifikasjoner å støtte oss til. Følgelig kan dette målet vise til uttalevarianter av typen dialekter og sosiolekter innenfor Storbritannia og USA, men det kan også vise til uttalevarianter fra verden for øvrig. Men selv om eleven ifølge M-87 både skal få høre eksempler på ulik engelsk uttale og også lære å respektere ulike uttalevarianter, så står følgende fast: Når det gjelder elevene selv, så "bør" de lære å bruke en "normalisert variant av britisk eller amerikansk engelsk" (s. 210). Med dette er de to tradisjonelle hovedvariantene av engelsk uttale likestilt.

Selv om tidligere planer også har vist til engelsk som kommunikasjonsmiddel $\mathrm{i}$ en enda videre sammenheng enn de tradisjonelle engelsktalende land og samveldelandene, tar M-87 i bruk betegnelsen engelsk som "internasjonalt språk”. Den foreskriver videre kjennskap til samfunnsområder der engelsk brukes i og utenfor Norge og hevder at elevene "skal få vite hvor engelsk er nasjonalspråk, fellesspråk og minoritetsspråk" (s. 207). Her har forfatterne hatt språket til brukere fra flere av Kachrus sirkler i tankene.

Det viktigste i Lœreplanverket for den 10-årige grunnskolen av 1997 (L-97), ut fra vårt perspektiv, er at læringsambisjonen når det gjelder ulike uttalevarianter er løftet et hakk opp: Elevene skal ikke bare høre eksempler på ulik uttale av det engelske språket, men på 9. klassetrinn skal de "oppfatte varianter av engelsk språk” (s. 231). ${ }^{7}$ Selv om L-97 omtaler engelsk som et verdensspråk, var en oppfatning i det engelskdidaktiske miljøet i Norge at planen ikke gikk langt nok på dette punktet: "Ikke på et eneste årstrinn vektlegges bruken av engelsk som internasjonalt språk” (Haukås, 2005, s. 44).

I den hittil siste læreplanen i rekken, Kunnskapsløftet av 2006 (K-06), konstateres det allerede i formålsavsnittet at “engelsk er et verdensspråk” (2014versjonen på Internett). ${ }^{8}$ Dette avsnittet viser også til hvilke deler av verden kulturkomponenten i engelskfaget skal hentes fra: “[...] engelskfaget [skal] bidra til å gi innsikt i levesett og kulturer der engelsk er hovedspråk eller et offisielt språk” (s. 2). Det betyr i land både i den "indre” og den "ytre” sirkelen gjengitt ovenfor. Målsettingen omfatter også at faget skal "gi innsikt i hvordan engelsk brukes som et internasjonalt kommunikasjonsmiddel" (2014-versjonen, s. 2, uthevet her). Dermed synes alle sirklene å være representert i læreplanen (jf. læreroppfatninger i Hansen, 2011, nedenfor). Slik innsikt skal dessuten, i følge planen, gi elevene et godt grunnlag blant annet for å forstå "utviklingen av engelsk som et verdensspråk”.

Tre steder i 2014-versjonen er det en klar poengtering av at elevene skal "forstå varianter av muntlig engelsk fra forskjellige deler av verden”, først i generelle ordelag i avsnittet om "grunnleggende ferdigheter" (s. 5). Dernest blir dette målet nivåspesifisert på ulike trinn som for eksempel "lytte til og forstå varianter av engelsk fra forskjellige autentiske situasjoner" i avsnittet om "kompetansemål etter 10. årstrinn” (s. 10) og endelig som "lytte til og forstå 
sosiale og geografiske varianter av engelsk i autentiske situasjoner" i avsnittet om "kompetansemål etter Vg1", læreplanens høyeste trinn (s. 11). Denne læreplanen åpner med andre ord for å hente inn uttalevarianter av engelsk fra alle de tre sirklene redegjort for ovenfor (jf. læreroppfatninger i Hansen, 2011, nedenfor).

\section{Studier av meninger, holdninger og praksis}

To studier undersøker meninger og holdninger hos norske elever til valg av uttalevariant. En av disse analyserer også valg av variant i to sentrale læremidler som elevene eksponeres for. Selv om disse studiene er gjennomført i videregående skole og ikke i grunnskolen, mener jeg de også i noen grad kan representere meninger og holdninger i grunnskolen. Jeg skal i tillegg kort omtale en lignende undersøkelse som omfatter engelsklærere på ulike trinn i skolesystemet.

I Ulrikke Elisabeths Rindals omfattende artikkelbaserte doktoravhandling (Rindal, 2013) kan vi blant annet lese at flertallet av elevene i en undersøkelse fra annen klasse i videregående skole hadde som mål for egen språkutvikling en innfødt variant av engelsk uttale, med en liten preferanse for amerikansk engelsk. Elevene mente videre at amerikansk engelsk er den letteste uttalevarianten å lære seg og også den mest "naturlige”, og følgelig foretrakk de den som opplæringsmodell. På den annen side mente de at britisk engelsk (Standard Southern British English) fortsetter å være den mest prestisjefylte uttalevarianten og holder stillingen som formell standard for engelskopplæringen. Rindal viser også til at noen elever satset på en nøytral uttalevariant, en variant som omtales som å være i en mellomstilling mellom etablerte varianter og som ikke kan forbindes med noe folk eller noen kultur fra de etablerte (Rindal, 2013; artikkel 2 og 3).

Mastergradsavhandlingen til Marie Tengs Sannes fanger også opp meninger og holdninger blant elever i annen klasse i videregående skole (Sannes, 2013). Resultater av studien viser at på spørsmål om elevene i egen opplæring satset på en spesiell uttalevariant, svarte de fleste nei (52,1 \% nei og 47,9 \% ja ). Blant de elevene som svarte ja, satset 33,3 \% på britisk engelsk og 29,8 på amerikansk engelsk. Studien viser videre at britisk engelsk blant annet oppfattes som intelligent, høflig, og vellykket, mens amerikansk engelsk hovedsakelig betraktes som lett å forstå, normal og tiltalende. Denne avhandlingen måler også holdninger til engelsk med sterk norsk uttale og med svak norsk uttale. Elevene reagerer sterkt negativt på førstnevnte, mens sistnevnte vurderes som akseptabel, normal, nøytral og lett å forstå.

Mastergradsavhandlingen til Sannes undersøker også lydmaterialet fra to av de mest brukte læreverkene i engelsk for videregående skole. ${ }^{9}$ Resultatene av 
disse undersøkelsene viser "at elever eksponeres for et større utvalg av uttalevarianter enn tidligere, men at det fortsatt er britiske og amerikanske eksempler som dominerer" (Sannes, 2013, s. iv). En konklusjon er videre at både elever og lærere

[...] ser på kommunikasjon, og det å gjøre seg forstått på engelsk, som hovedmålet for språkopplæringen. Selv om det finnes en viss forståelse for at man ikke behøver å snakke engelsk som en morsmålsbruker for å gjøre seg forstått, ser det likevel ut til at native speaker-normen står sterkt (op.cit.). ${ }^{10}$

Den tredje studien som tas med her, er Thomas Hansens mastergradsavhandling, hvor han blant annet gjennomførte en spørreskjemaundersøkelse blant engelsklærere på ulike nivåer i skolesystemet (Hansen, 2011). Hans mål med studien var å finne ut hvilken av de to modellene, the native-speaker model eller the intercultural-speaker model, som hadde prioritet hos lærerne. Med flere forbehold hva angår både omfang av undersøkelsen og forskningsmetode anvendt, mener forfatteren at en tendens i svarene er at the intercultural speaker model først og fremst anerkjennes som modell for kulturundervisningen i engelskfaget, men at den innfødte talers modell foretrekkes som mål for elevenes egen språktilegnelse. Studien viser dessuten at elevenes evne til å tilegne seg en tilnærmet innfødt uttale og intonasjon, påvirker lærernes evaluering av elevenes kompetanse $\mathrm{i}$ faget $\mathrm{i}$ en positiv retning. Hansen viser videre til at en tendens $\mathrm{i}$ studien er at kulturer og språkvarianter $\mathrm{i}$ den "voksende" sirkelen ikke betraktes av lærerne som del av den engelsktalende verden som den gjeldende læreplan, K-06, refererer til.

Som redegjort for ovenfor spådde Modiano at en Midt-Atlantisk variant, kort definert som en "mixing of AmE and BrE", ville komme til å erstatte britisk engelsk som foretrukket standard for engelskfaget i de europeiske utdanningssystemene. Studiene gjengitt ovenfor har ikke stilt spørsmål som kan gi noe entydig svar på det. Imidlertid kan resultater som viser at noen elever satset på en nøytral uttalevariant og at en høy prosent av elevene ikke satset på noen spesiell uttalevariant, indikere noe i retning av en slik tendens.

\section{Diskusjon om veien videre}

Det er engelsken innenfor den "voksende" sirkelen som har utgjort det mest intenst diskuterte og utfordrende temaet i de internasjonale fagdidaktiske miljøene etter tusenårsskiftet. Vi har for eksempel observert radikale forslag til endring av den språklige modellen for den formelle opplæringen i engelsk. Som redegjort for i avsnittet "Engelsk som lingua franca: en utfordrende debatt", har flere teoretikere deltatt i debatten og blant annet pekt på at hvis det er slik at brukerne av engelsk som fremmedspråk i stadig sterkere grad hovedsakelig bruker språket i kommunikasjon med andre brukere av engelsk som annetspråk 
eller fremmedspråk og i stadig mindre grad i kommunikasjon med talere av engelsk som førstespråk, så burde en i opplæringen ta konsekvensen av det og forberede elever og studenter på bruk av ELF framfor bruk av en innfødt engelskvariant.

Slike vidtgående forslag har blitt sterkt imøtegått blant annet med følgende motargumenter. ELF er ingen stabil språkvariant og utgjør derfor ikke noen egnet modell for opplæringen: "[...] I have argued that since we have no ELF variety, and since learners are oriented towards the native-speaker standard, the native norm should remain the teaching model in the Expanding Circle" (jf. Mollin, 2006b, s. 54). Et tungt argument har videre vært at ELF ikke har noen tilfredsstillende beskrivelse, kodifisering, hvilket normalt regnes som en nødvendighet i en formell opplæringssammenheng. Men på sikt, i følge Seidlhofer, kan problemet med kodifisering bli løst. I en diskusjon om ELF som undervisningsfag hevder hun at "the crucial recent innovation is that linguistic descriptions that teaching professionals can refer to if they so wish are becoming available” (Seidlhofer, 2004, s. 225).

Fra undervisningspraktisk hold er et viktig spørsmål om en kan forvente at alle lærerne er oppdatert på dagens bruk av ELF, og et sentralt spørsmål blir videre hva kriteriene for en evaluering av elevenes språkkompetanse, i vår sammenheng uttale, skal bygge på. Kan en for eksempel uten videre regne med at alle uttalevarianter fremstår som likeverdige for sensorene (jf. omtalen av M87 ovenfor)? Uten klare evalueringskriterier er det lite sannsynlig at skolesystemet kan sikre en likebehandling av elevene.

Det er faktisk stor forskjell mellom anbefalingene på den ene siden hos de mest markante forkjemperne for ELF som modell, og på den annen side holdninger og meninger hos norske elever og lærere, hvor en britisk engelsk eller en amerikansk engelsk native speaker norm foretrekkes som modell for opplæringen. Hansen peker på at i diskusjonen om modell må ikke elevenes egne forventninger om hvilket språkideal som skal gjelde for dem, undervurderes (Hansen, 2014). Og Rindal viser i sin avhandling til mangelen på retningslinjer for elevenes uttale i det nasjonale læreverket for engelsk, K-06, og mener at dette utløser et behov for rettledning for lærerne (Rindal \& Piercy, 2013, s. 225). Hansen viser til at muntlige vurderingskriterier i dag er delegert til lokale kommunale og fylkeskommunale skoledistrikter, og han gir eksempel på at kriteriene varierer (Hansen, 2014). Det synes med andre ord å være atskillig usikkerhet om bestemte sider av dagens skolefag. Det kan skape forvirring blant lærerne.

Selv om Mollin, som pekt på ovenfor, går i mot ideen om å gjøre engelsk som lingua franca til modell for opplæring, så hevder hun at dette ikke innebærer "that training for successful lingua franca communication should not take place” (Mollin, 2006b, s. 54). Dette er også i samsvar med det synspunkt Modiano hevdet i sin artikkel av 1996, som redegjort for ovenfor: å inkludere øving i å forstå uttalen til brukere av andre engelskvarianter. På dette punktet 
synes norske læreplaner til dels å uttrykke samme syn fra og med M-87. At elevene i oppøvingen av den muntlige reseptive ferdigheten for eksempel skal eksponeres for ulike uttalevarianter av engelsk, er med andre ord fullt og helt i samsvar i læreplanene de siste to-tre tiårene. Klarest ser vi det i K-06 hvor faget blant annet skal gi innsikt i hvordan engelsk brukes som internasjonalt kommunikasjonsmiddel. Men med dette menes etter all sannsynlighet hovedsakelig uttalevarianter fra den "indre" og den "ytre" sirkelen, og kanskje i mindre grad fra den "voksende" sirkelen som en av undersøkelsene omtalt ovenfor synes å indikere (jf. Hansen, 2011).

Mollin mener videre at elevene "should also be made aware of the strategies of lingua franca communication, of how to effectively accommodate to somebody whose mother tongue is also not English" (op.cit.). Dette er også i noen grad i samsvar med det Modiano gikk inn for for knapt 20 år siden. Slike fremgangsmåter omtales gjerne i faglitteraturen som kommunikasjonsstrategier. Blant disse står tillemping av språk og uttrykksformer sentralt, (accommodation eller foreigner talk), i samtale med språkbrukere med svakere språkkompetanse enn den en selv har (se Simensen, 2007, s. 95-96, s. 99 og s. 157).

I Norge står dialektene sterkt, og norske elever eksponeres normalt for en rekke ulike dialektvarianter både innenfor og utenfor utdanningssystemet. Det skulle derfor ligge godt til rette for øving i å forstå forskjellige uttalevarianter av engelsk i skolen.

Men likevel, på området ELF er det verdt å merke seg at Martin Deweys undersøkelse har avdekket en rekke konflikter mellom teori og virkelighet, og han anbefaler derfor på det sterkeste samarbeid mellom praktiserende lærere og skolepolitikere, engelskdidaktikere osv. om veien videre. For å låne et utsagn av Martin Dewey: Engelsk som lingua franca er "a nice idea but a bit pie-in-thesky” (Dewey, 2012, s. 152).

\section{Oppsummering og konklusjon}

Engelsk som obligatorisk fag i folkeskolen startet som en britisk engelsk variant av språket i 1939. Først i 1987, etter nærmere 50 år, blir en normalisert variant av britisk engelsk og amerikansk engelsk likestilt. Dette året skal elevene også lære å respektere ulike uttalevarianter av det engelske språket som likeverdige. I 1997 skal elevene oppfatte varianter av engelsk språk, og i 2006 skal elevene lære å forstå varianter av muntlig engelsk fra forskjellige deler av verden. Den rollen som engelsk spiller som kommunikasjonsmiddel ellers i verden nevnes i læreplanen av 1974, og i 1987 brukes betegnelsen "engelsk som internasjonalt språk”, i 1997 "engelsk som verdensspråk” og i 2006 engelsk "som et internasjonalt kommunikasjonsmiddel”. 
Utviklingen i den perioden som er studert i denne artikkelen, viser også en utvidelse av engelskfaget som kunnskapsfag, og kulturkomponenten synes i noen grad å ha vært en drivkraft i å åpne opp for ulike "engelsker”, inklusive uttalevarianter i klasserommet. Men nye visjoner fra teoretisk hold de siste årene om å gjøre engelsk som lingua franca til språkmodell, har ikke fram til nå fått fotfeste i norske retningsgivende læreplandokumenter. Slike ideer har heller ikke fått støtte i en nyere undersøkelse av holdninger og meninger hos praktiserende lærere. Den innfødte talers modell foretrekkes som mål for elevenes egen språktilegnelse.

Undersøkelser blant norske elever i dag om preferanse for britisk engelsk eller amerikansk engelsk som uttalevariant gir ikke noen klare svar. Elevene mener at britisk engelsk uttale i evalueringssammenheng blir noe høyere verdsatt av lærerne. Og studien av lærere i samtiden viser også at elevenes evne til å tilegne seg en tilnærmet innfødt uttale og intonasjon, påvirker lærernes evaluering av elevenes kompetanse i faget i en positiv retning.

Det er behov for mye forskning og utviklingsarbeid, inklusive konsekvensvurderinger, når et skolefag skal endre kurs, også på feltet engelskvariant. En rekke interesser og virkninger må overveies. Blant de viktigste er spørsmålet om hva som tjener våre elever best så vel ut fra sosiale som utdannings- og yrkesrelaterte hensyn.

\section{Litteratur}

Baldridge, J. (2002). Linguistic and social characteristics of Indian English. Language in India 2(4). http://www.languageinindia.com/junjul2002/baldridgeindianenglish.html (hentet 25.10.2013).

Berns, M. (2009). English as lingua franca and English in Europe. World Englishes, 28, 2, s. 192-199. http://onlinelibrary.wiley.com/doi/10.1111/j.1467971X.2009.01578.x/abstract (Hentet 25.10.2013).

Bolton, K. (2005). Where WE stands: approaches, issues, and debate in World Englishes. Symposium on World Englishes Today (Part II). World Englishes, 24, (1), s. 69-93. http://onlinelibrary.wiley.com/doi/10.1111/j.0883-2919.2005.00388.x/pdf (Hentet 03.03.2014).

British Council. http://www.britishcouncil.org/learning-faq-the-english-language.htm (Hentet 11.10.2013).

Burt, C. (2005). What is international English? Teachers College, Columbia University Working Papers in TESOL and Applied Linguistics, 5(1), s. 1-20.

Byram, M. (red.). (2000). The Routledge encyclopedia of language teaching and learning. London: Routledge.

Crystal, D. (1997). English as a global language. Cambridge: Cambridge University Press.

Curriculum for the 10-year compulsory school in Norway. (1999). Oslo: The Royal Ministry of Education, Research and Church Affairs.

Dewey, M. (2012). Towards a post-normative approach: learning the pedagogy of ELF. Journal of English as a Lingua Franca, 1(1), s. 141-170. http://www.degruyter.com/view/j/jelf.2012.1.issue-1/jelf-2012-0007/jelf-20120007.xml (hentet 11.03.2014). 
Gnutzmann, C. (2000). Lingua franca. I M. Byram. (red.), The Routledge encyclopedia of language teaching and learning. ( s. 356-359). London: Routledge.

Graddol, D. (1997). The future of English. A guide to forecasting the popularity of the English language in the 21st century. London: The British Council. http://www.britishcouncil.org/learning-elt-future.pdf (hentet 13.03.2014).

Gundem, B. B. (1989). Engelskfaget i folkeskolen: Påvirkning og gjennomslag fra 1870-årene til først på 1970-tallet. Oslo: Universitetsforlaget.

Hansen, T. (2011). Speaker models and the English Classroom: The impact of the intercultural-speaker teaching model in Norway (MA thesis). Halden: Høgskolen i Østfold

Hansen, T. (2014). Språknormer. I C. Bjørke, Dypedahl, M. \& Myklevold, G.-A. (red.), Fremmedspråksdidaktikk. Oslo: Cappelen Damm Akademisk.

Harmer, J. (2007). The practice of English language teaching (4 utgave). Harlow: Longman.

Haukås, Å. (2005). De nye læreplanene og engelsk som internasjonalt språk. Språk og Språkundervisning. s. 44-46.

Hickey, R. (2012). Codified varieties around the world. Cambridge: Cambridge University Press.

Jenkins, J. (2000). The phonology of English as an international language. Oxford: Oxford University Press.

Jenkins, J. \& Seidlhofer, B. (2001). Bringing Europe’s lingua franca into the classroom. The Guardian, 19.04.2001.

http://education.guardian.co.uk/higher/languages/story/0,,475471,00.html (hentet 19.02.2013).

Jenkins, J., Cogo, A. \& Dewey, M. (2011). Review of developments in research into English as a lingua franca. State-of-the art article. Language Teaching, 44(3), s. 281-315. http://journals.cambridge.org/action/displayFulltext?type=1\&pdftype=1\&fid=8271755 \&jid=LTA\&volumeId=44\&issueId=03\&aid=8271753 (Hentet 03.06.2014).

Kachru, B. B. (red). (1982). The other tongue: English across cultures. Urbana, Ill.: University of Illinois Press.

Kachru, B. B. (1986). The alchemy of English: The spread, functions, and models of nonnative Englishes. Oxford: Pergamon.

Kachru, B. B. (1992). Indian English. I T. McArthur, (red.), The Oxford Guide to World English. Oxford: Oxford University Press.

Kachru, B. B. (1996). World Englishes: Agony and ecstasy. Journal of Aesthetic Education, 30(2), s. 135-155.

Kirkpatrick, A. (2007). World Englishes: Implications for international communication and English language teaching. Cambridge: Cambridge University Press.

Kunnskapsdepartementet. (2006). Kunnskapsløftet. Læreplan i engelsk. (K-06). http://www.udir.no/kl06/ENG1-03/Hele/Formaal/ (2014-versjonen; hentet 07.02.2014).

Lund, R. (2007). Questions of culture and context in English language textbooks. A study of textbooks for the teaching of English in Norway (doktorgradsavhandling). Bergen: Universitetet i Bergen.

Lœreplan for forsøk med 9-årig skole. Forsøk og reform i skolen, (1960). Engelsk. (L-60). Oslo: H. Aschehoug \& Co. (W. Nygaard).

Lcreplanverket for den 10-årige grunnskolen. (1997). Engelsk. (L-97). Oslo: Kirke-, utdannings- og forskningsdepartementet.

http://www.nb.no/nbsok/nb/adf3c4f27b9b41b8e2f231a54988bd42?index=0\#0 (hentet 04.05.2014). 
McArthur, T. (2003). World English, Euro-English and Nordic English? English Today, 19 (1), s. $54-58$.

http://literature.proquest.com/pageImage.do?ftnum=1396981431\&fmt=page\&area=crit icism\&journalid=02660784\&articleid=R01717716\&pubdate $=2003$ (hentet 01.03.2014).

Modiano, M. (1996). The Americanization of Euro-English. World Englishes, 15, 2, s. $207-$ 215. http://onlinelibrary.wiley.com/doi/10.1111/j.1467-971X.1996.tb00106.x/pdf (Hentet 01.03.2014).

Mollin, S. (2006a). Euro-English. Assessing variety status. Tübingen: Gunter Narr Verlag. Mollin, S. (2006b). English as a lingua franca: A new variety in the new expanding circle? Nordic Journal of English Studies, 5(2), s. 41-57.

http://ojs.ub.gu.se/ojs/index.php/njes/article/view/67/71 (hentet 29.10.2013).

Mønsterplan for grunnskolen. (1974). Engelsk. (M-74) Oslo: Aschehoug.

Mønsterplan for grunnskolen. (1987). Engelsk. (M-87) Oslo: Aschehoug.

Normalplan for byfolkeskolen. (1939). Oslo. (Forlagt av H. Aschehoug \& Co.).

Plan for en engelskundervisning for alle. Barne- og ungdomsskolen for alle tar form. Forsøk og reform i skolen, 2. (1957). (P-57). Oslo: I kommisjon hos H. Aschehoug \& Co. (W. Nygaard).

Rindal, U. (2013). Meaning in English: L2 attitudes, choices and pronunciation in Norway. (doktorgradsavhandling). Oslo: Universitetet i Oslo.

Rindal, U. \& Piercy, C. (2013). Being 'neutral'? English pronunciation among Norwegian learners. World Englishes, 32(2), s. 211-229. http://onlinelibrary.wiley.com/doi/10.1111/weng.12020/pdf (hentet 01.06.2014).

Sannes, M. T. (2013). From the native speaker norm towards English as an international language. A study of exposure and attitudes to native and non-native varieties in the teaching of English in Norway (masteravhandling). Bergen: Universitetet i Bergen.

Seidlhofer, B. (2004). Research perspectives on teaching English as a lingua franca. Annual Review of Applied Linguistics, 24, s. 209-239.

http://literature.proquest.com/searchFulltext.do?id=R04229427\&divLevel=0\&area=ab ell\&forward=critref_ft (hentet 03.03.2014).

Shoba, J. A. \& Quarcoo, M. (2012). English in the mix: Evolving roles of English in the language practices of Twi speakers in Ghana. Language Matters: Studies in the Languages of Africa, 43(1), s. 77-96. http://www.tandfonline.com/doi/pdf/10.1080/10228195.2012.654501 (Hentet 03.06.2014).

Simensen, A. M. (2007). Teaching a foreign language. Principles and procedures. Bergen: Fagbokforlaget.

Simensen, A. M. (2011). Europeiske institusjoners rolle i utviklingen av engelskfaget i norsk skole. Didaktisk Tidskrift, 20(3), s. 157-181.

Steiner, G. (1975). After Babel: aspects of language and translation. Oxford: Oxford University Press.

Stensaasen, S. (1958). Gjennomføringen av engelskundervisningen i folkeskolen. I J. Sandven \& Stensaasen, S. (red.), "Samleskrift fra Universitetets Pedagogiske Forskningsinstitutt." Forskning og danning, 4. Oslo: J.W. Cappelens Forlag.

\footnotetext{
${ }^{1}$ Det eksisterte to Normalplaner, en for byfolkeskolen og en for landsfolkeskolen. Jeg bruker førstnevnte her.

${ }^{2}$ http://www.britishcouncil.org/learning-faq-the-english-language.htm (Hentet 11.10.2013).
} 


\footnotetext{
${ }^{3}$ Flere forfattere innen dette feltet peker på at skillene mellom de tre opprinnelige typer brukere er i ferd med å viskes ut, og at det for eksempel finnes språkbrukere i den "voksende" sirkelen som har høyere kompetanse i språket enn språkbrukere i den "ytre” sirkelen. McArthur, 2003, kommer med en rekke gode eksempler. ${ }^{4}$ Se det elektroniske verdensatlaset for engelskvarianter http://www.ewave-atlas.org/languages (Hentet 11.10.2013).

${ }^{5}$ Bolton (2005) gir en nyttig oversikt over ulike tilnærminger til og sentrale spørsmål i debatten om de mange slags "engelsker" de siste tre tiårene.

${ }^{6}$ Terminologien diskuteres for eksempel i Jenkins, Cogo \& Dewey (2011). Se også Berns (2009).

${ }^{7}$ I den engelsk oversettelsen av L-97 står det "be able to distinguish between varieties of English". The curriculum for the 10-year compulsory school in Norway. (1999). Oslo: The Royal Ministry of Education, Research and Church Affairs. (Støtteark, ikke paginert).

${ }^{8}$ Engelsk i Kunnskapsløftet utgjør et obligatorisk fag for alle elever i grunnskolen og for alle elever som fortsetter til videregående skole. Formålsparagrafen i faget gjelder derfor hele utdanningsløpet fra 1. trinn i grunnskolen til og med 11. trinn, det vil si 1. trinn i videregående skole.

${ }_{9}^{9}$ Ragnhild Lunds avhandling fra 2007 tangerer målsettingen med denne artikkelen. Et utgangspunkt er omtalen av engelsk som verdensspråk i L-97. Undersøkelsen omfatter fire lærebokserier for ungdomstrinnet i grunnskolen, produsert i samsvar med L-97, hvor et sentralt poeng er behovet hos fremmedspråkelever for å utvikle evnen til å kommunisere på tvers av kulturelle skillelinjer. Analysen av kulturkomponenten er følgelig sentral. Den viser at læreboktekster med emner relatert til Storbritannia og USA dominerer. Men også tekster fra andre engelsktalende land og tekster fra ikke-engelsktalende land er representert, så vel skjønnlitterære tekster som sakprosatekster. Lærebokseriene kommer med lydmateriale (CD-er), men en analyse av uttalevarianter i dette lydmaterialet inngår ikke i Lunds undersøkelse (Lund, 2007).

${ }^{10}$ Praktiske forhold gjorde at bare meninger og holdninger til en liten gruppe av engelsklærere i pilotstudien ble tatt med i mastergradsavhandlingen.
} 